\title{
An Institutionalist Perspective on the Global Financial Crisis
}

Charles J. Whalen, Utica College

April 2009

\begin{abstract}
This essay, prepared for a forthcoming collection of perspectives on the current world economic crisis, offers an institutionalist viewpoint on the financial crisis at the center of world attention since mid-2008. It is divided into three sections. The first section provides a brief history of the institutionalist understanding of how an economy operates, with special emphasis on a tradition known as post-Keynesian institutionalism (PKI). The second section draws on PKI to offer an explanation of the global financial crisis. The third section identifies some of the public-policy steps that are required to achieve a more stable and broadly shared prosperity in the United States and abroad. At the heart of PKI is attention to unemployment and the broader economic concerns facing working families. That focus is rooted in the shared interests of John R. Commons and John M. Keynes, who saw the business cycle as an important cause of unemployment and recognized that attaining greater economic stability requires understanding the operation and evolution of financial institutions.
\end{abstract}

4/24/09. Prepared for Alternative Perspectives on the World Financial Crisis, edited by Steven Kates (Cheltenham, UK: Edward Elgar, forthcoming). 


\section{An Institutionalist Perspective on the Global Financial Crisis}

Charles J. Whalen

Professor of Business and Economics, Utica College

Visiting Fellow, Cornell University ILR School

E-mail: cjwhalen@cornell.edu

\section{INTRODUCTION}

This chapter presents an institutionalist perspective on the financial crisis that has been at the center of world attention since mid-2008. It is divided into three sections. The first section provides a brief history of the institutionalist understanding of how an economy operates, with special attention to how this understanding differs from that offered by neoclassical economics. The second section outlines an institutionalist explanation of the global financial crisis. The third section identifies some of the public-policy steps that are required to achieve a more stable and broadly shared prosperity in the United States and abroad.

The particular variant of institutional economics that informs this chapter is what can be called post-Keynesian institutionalism (PKI). This strand of institutionalist thought, which emerged in the United States in the early 1980s, is rooted in the contributions of Thorstein B. Veblen (1857-1929), Wesley C. Mitchell (1874-1948), and John R. Commons (1862-1945), but also benefits from the insights of John Maynard Keynes (1883-1946) and even Joseph A. Schumpeter (1883-1950). The publications of Hyman P. Minsky (1919-1996) were a model of PKI in the 1980s and 1990s, and his ideas remain relevant today. In addition to the author of this chapter, recent contributors to PKI include Martin H. Wolfson, David A. Zalewski, Kenneth P. Jameson, Slim Thabet, Chris Niggle, Fadhel Kaboub, Eric Tymoigne, L. Randall Wray, and Zdravka Todorova. 


\section{HOW AN ECONOMY OPERATES}

In a 1996 essay, institutionalist William M. Dugger observed that institutional economists have traditionally been 'notoriously independent cusses, so getting them all within the perimeters of a manageable definition is not easy—it is a bit like herding stray cats' (Dugger 1996, 31). In this chapter, that challenge is compounded because PKI draws on several strands of economic thought. Thus, instead of a roundup, this section offers an aerial survey: a historical overview of relevant institutionalist perspectives on how an economy operates, with attention to their divergence from mainstream economics.

\section{Scope, Focus and Point of View}

Institutional and neoclassical economics have always differed in scope. Neoclassical economics involves the study of market economies; its theories are not equipped to study a command economy or pre-capitalist economy (Heilbroner 1996). In contrast, institutional economics involves the much broader study of 'social provisioning' - it is interested in the what, how and why of all aspects of production and distribution by humans, regardless of whether those processes involve markets or not (Dugger 1996).

This difference in scope leads to an essential difference in focus. Neoclassical economics focuses on the price mechanism, and considers the adjustment of prices to be the key regulating force in an economy. In contrast, institutionalism focuses on social institutions, and views them as the key to economic regulation. Indeed, according to institutionalist Yngve Ramstad, a 'central insight' of the institutional school is that institutional adjustment is 'the balancing wheel of the economy’ (Ramstad 1985, 509).

To be sure, institutionalists study market economies, but their different focus yields an alternative conception of how such economies operate. Since the days of Veblen, institutionalists 
have stressed that the difference between their approach to studying capitalist economies and the approach of the mainstream boils down to a different 'point of view:' neoclassical economics assumes the price system is self-regulating, while institutional economics does not (Veblen 1898).

\section{Veblen, Mitchell and Commons}

The neoclassical and institutionalist conceptions of market economies produce divergent research streams. Mainstream economics devotes much attention to identifying the normal conditions and long-run tendencies that are consistent with its fundamental preconception regarding price adjustments. Institutional economics seeks instead to understand the actual evolution of social institutions. In fact, this was the orientation Veblen advocated in 1898, when he wrote, 'There is the economic life process still in great measure awaiting theoretical formulation’ (Veblen 1898, 387).

Financial crises were among the aspects of the economic life process incorporated into the theories of Veblen and his student, Mitchell (Veblen 1904; 1923; Mitchell 1913; 1927). That is not surprising; such crises appeared to be an integral part of the business cycles that occurred regularly in their lifetime (Wolfson 1986, 15). However, such crises and cycles received little attention from conventional economists. As Mitchell noted in 1927, 'It was not the orthodox economists who gave the problem of crises and depressions its place in economics;' to scholars in the economic mainstream, such issues did not rank 'among the central problems of economic theory’ and were ‘of secondary interest’ at best (Mitchell 1927, 3-4).

While Mitchell was much more interested in using theory to resolve immediate economic problems than Veblen, perhaps the most outspoken 'problem solver' of the early institutionalists was Commons. Motivated by an interest in the issues of concern to working people, Commons 
was drawn to a study of the credit system and business cycles. According to Commons, 'Unemployment is the outstanding defect of capitalism;' the business cycle was the most important cause of unemployment; and the credit cycle was at the root of the business cycle (Lewisohn et al. 1925, 52; Commons 1922). Thus, attacking these issues were at the heart of his career-long attempt to ‘save capitalism by making it good' (Commons 1934, 143; Whalen 1993).

\section{Keynes and the Keynesian Revolution}

Keynes, of course, was in many respects on the same mission as Commons (Atkinson and Oleson 1998). Moreover, Keynes and Commons corresponded and occasionally exchanged papers. In one letter to Commons, Keynes famously wrote, '[T]here seems to be no other economist with whose general way of thinking I feel myself in such genuine accord' (Keynes 1927).

In a series of lectures and articles written in the 1920s and 1930s, Keynes distinguished his view of how the capitalist system operates from that of mainstream economists. He differed from the mainstream, Keynes argued, due to rejection of the conventional belief that 'the existing economic system is in the long run self-adjusting' (Keynes 1935, 35). As he wrote in 1925, 'On the one side the Treasury and the Bank of England are pursuing an orthodox nineteenth-century policy based on the assumption that economic adjustments can and ought to be brought about by the free play of the forces of supply and demand.... On the other side, not only the facts, but public opinion also, have moved a long distance away in the direction of Professor Commons's epoch of stabilization' (Keynes 1972, 305).

The 'epoch of stabilization’ to which Keynes refers is a stage of world economic history outlined in Reasonable Value, a 100-page manuscript that Commons eventually developed into Institutional Economics (Commons 2008; Whalen 2008d). From Keynes's discussion of 
Commons's eras of scarcity, abundance and stabilization (which appears in two 1925 essays), it is clear both economists appreciated that institutional change affects an economy's performance and policy needs (Keynes 1972; 1981). The institutionalist literature has even demonstrated that the determinants of national output and employment presented in The General Theory of Employment, Interest and Money are historically contingent and institutionally determined (Chase 1975; Foster 1981a; Foster 1981b; Crotty 1990). ${ }^{2}$

Despite Keynes’s affinity with the non-neoclassical ideas of Commons, the Keynesian revolution in economics was quickly defused and The General Theory was soon co-opted by the economic mainstream. Through the work of John R. Hicks, Paul A. Samuelson, James Tobin, and others, Keynes’s insights became merely a special case in a macroeconomic theory compatible with the pre-Keynesian mainstream and neoclassical microeconomics. In the 1950s and 1960s, that macro theory reached the peak of its popularity and was widely regarded as an adequate guide to U.S. fiscal policy and aggregate-demand management, which boiled down to 'fine tuning' in response to exogenous disturbances. Instead of adopting a dynamic, businesscycle perspective, macroeconomic analysis was heavily oriented toward comparative statics.

In the 1970s and early 1980s, however, the Keynesian-neoclassical synthesis was under attack for inadequately addressing stagflation and the resurgence of financial instability. In the realm of theory, the macroeconomic mainstream distanced itself further from Keynes by embracing the notion of a natural rate of unemployment and even New Classical macroeconomics, which defines away the problem of unemployment by dismissing the possibility that joblessness can be involuntary. With respect to policy, meanwhile, the mainstream moved toward monetarism and later to inflation targeting. The case for activist demand management became more dependent than ever on the existence of 'market 
imperfections,' such as rigid wages, which could rarely be used to justify more than short-term government action.

\section{Post-Keynesian Institutionalism}

A number of institutionalists responded to the assault on mainstream Keynesianism in a very different manner: by emphasizing the common ground between their approach and that of Keynes. This opened the door to the emergence of PKI. Wallace C. Peterson, for example, used his 1976 presidential address before the institutionalists’ Association for Evolutionary Economics (AFEE) to underscore the overlapping 'bedrock, seminal ideas in institutionalism and Keynes.' He began, not surprisingly, by drawing attention to the fact that The General Theory describes an economic system 'inherently flawed' due to 'intractable cyclical instability' and by observing that 'the neoclassical synthesis cut Keynes loose from real, historical time.' According to Peterson, 'Leaving history and its uncertain movement out of the analysis imparts a false sense of determinacy and predictability to the economic process’ (Peterson 1977, 202, 213-214).

Dudley Dillard, W. Robert Brazelton, and Robert R. Keller also helped pave the way for PKI. Dillard stressed that financial institutions play a critical role in the economics of Veblen, Mitchell and Keynes and that each had 'what may be called a monetary theory of production' (Dillard 1980, 255). Brazelton drew attention to microeconomic and macroeconomic compatibilities in institutional economics, The General Theory and the emerging post Keynesian economics associated with the work of Sidney Weintraub, Daniel R. Fusfeld, and a small number of other Americans (Brazelton 1981). Keller, meanwhile, stressed institutionalist and post Keynesian complementarities; for example, the former gave more attention to the case for constructive state involvement in the economy, while the latter produced more detailed analyses of problems such as stagflation (Keller 1983). 
Stagflation is one of the central problems addressed in the first book to analyze the economy from a PKI perspective, An Inquiry into the Poverty of Economics by Charles K. Wilber and Kenneth P. Jameson (1983). Drawing on Keynes’s belief that the economy is inherently unstable and on the institutionalist tradition pioneered by Veblen, Mitchell and Commons, Wilber and Jameson gave special attention to John Kenneth Galbraith’s notion of a bifurcated economic system—a 'planning sector' with about a thousand oligopolistic corporations and a 'market sector' with millions of small firms wielding little or no market power. Key chapters of their book focused on how these two sectors and government interacted to affect output, employment and prices.

In a rapidly changing economy, however, the Wilber and Jameson volume fell out of date quickly. Even more than a book centered on the condition of stagflation, PKI needed attention to the dynamics of business cycles and postwar capitalist development. In the wake of An Inquiry into the Poverty of Economics, Hyman P. Minsky came closest to providing what was required. He also integrated key insights from Schumpeter into the PKI conception of how the contemporary economy operates.

\section{Minsky's PKI}

Although Minsky may have been most often labeled a 'post Keynesian’ economist, he maintained a close relationship with institutionalists throughout his career and eventually

considered himself both an institutionalist and a post Keynesian (Whalen 1996; Whalen 2008e). ${ }^{3}$ In the early 1980s, Minsky and his colleague Steven Fazzari were selected to contribute an article on monetary policy to a special economic-policy issue of AFEE's Journal of Economic Issues (Fazzari and Minsky 1984). In the late 1980s, another special issue of that journal was organized to highlight institutionalist research and Minsky’s ideas on financial instability were 
featured prominently in the chapters on money and macroeconomics (Dillard 1987; Peterson 1987).

Minsky's main contribution on financial instability is called the 'financial instability hypothesis.' Simply stated, it maintains that the capitalist financial system tends to cycle endogenously from a conservative state of affairs called hedge financing, to a more risky form called speculative financing, to an unsustainable form called Ponzi financing, and then back to hedge financing for another round. This hypothesis contrasts sharply with mainstream's 'efficient market hypothesis,' which assumes investors, lenders, and other financial-market participants are not collectively predisposed to overconfidence and other biases. Without timely and appropriate public intervention, the financial-instability cycle can have far-reaching macroeconomic consequences: a period of moderate prosperity can be quickly transformed into a boom, which can even more rapidly unravel and produce a deep recession (Minsky 1992a; 1986a, 206-213).

According to Minsky, the financial instability hypothesis is rooted in a view of the world shared by Keynes and Mitchell. Both looked at the economy of their time and saw a world in which Wall Street and other major financial centers play a critical role (Minsky 1990, 72; 1993; 1975, 57-58). In contrast to conventional macroeconomics, which Minsky viewed as having simply added money and financial assets to an analysis based on a barter economy, Minsky argued that the insights of Keynes and Mitchell could be fashioned into what might be called the ‘modern Keynesian’ view:

The modern Keynesian view begins with the creation and control of resources under actual (real world) capitalist conditions. Keynesian analysis is institutionally specific; it analyzes a capitalist economy with a sophisticated banking and financial system 
whose principal activity is financing business. This means that in each period capitalasset-owning and -using businesses have to pay funds to banks because prior financing contracts fall due. The Wall Street vision of businesspeople and bankers negotiating liability structures to finance asset holdings and activity, and these liability structures being validated or repudiated by events that happen in calendar time, is the essential theoretical and institutional structure upon which Keynesian theory is based (Fazzari and Minsky 1984, 106).

In Minsky's modern Keynesian view, financial instability and business cycles are inherent in a capitalist economy with a 'Wall Street' institutional structure and expensive, long-lived capital assets (i.e., specialized types of plant and equipment). However, Minsky also recognized that business cycles are not simply fluctuations within a fixed economic structure. Instead, cycles represent both a cause and consequence of changes to that structure (Minsky 1986a). As Mitchell wrote, a major challenge for the business cycle theorist is that 'each new cycle presents idiosyncrasies' (Mitchell 1941, ix). ${ }^{4}$

Minsky outlined his modern Keynesian perspective in a book and articles published in the mid-1970s (including Minsky 1975; 1982, 59-70), but by the mid-1980s he was concerned that decades of cumulative changes in U.S. financial relations and institutions had produced a new form of capitalism (Minsky 1986b). As a result, he turned to the writings of Schumpeter, his professor and graduate advisor at Harvard, for insight into long-term capitalist development. In an essay written for the hundredth anniversary of the birth of Keynes and Schumpeter, Minsky wrote:

Further progress in understanding capitalism may very well depend upon integrating Schumpeter's insights with regard to the dynamics of a capitalist process and the role 
of innovative entrepreneurs into an analytical framework that in its essential properties is Keynesian. Capitalism has exhibited both fragility and resiliency over the century since the death of Marx and the birth of Keynes and Schumpeter. Keynes's analytical structure enables us to understand and even cope with the fragility of capitalism. Schumpeter's vision of entrepreneurship helps us understand the resilience of capitalism and in particular how policy reactions to slumps that reflect Keynesian insights lead to resilience and add new dimensions to the fragility of financial structures (Minsky 1986c, 113).

Summarizing his position, Minsky added: 'The task confronting economics today may be characterized as a need to integrate Schumpeter's vision of a resilient intertemporal capitalist process with Keynes's hard insights into the fragility introduced into the capitalist accumulation process by some inescapable properties of capitalist financial structures’ (Minsky 1986c, 121).

The result is Minsky's theory of U.S. capitalist development. According to this theory, the evolution of capitalism is shaped by the institutional structure, which is always changing as a consequence of profit-seeking activity. The financial system takes on special importance in the theory because while production precedes exchange, finance precedes production. In addition, as Minsky learned directly from Schumpeter, 'Nowhere are evolution, change and Schumpeterian entrepreneurship more evident than in banking and finance and nowhere is the drive for profits more clearly the factor making for change' (Minsky 1993, 106). Moreover, since there is a symbiotic relationship between finance and industrial development, financial evolution profoundly affects the course of capitalist development.

Public policy is also an essential element in Minsky's theory. Government action is an inescapable determinant of capitalist evolution: Policy affects 'both the details and the overall 
character of the economy,' wrote Minsky in 1986. Thus, 'economic policy must be concerned with the design of institutions as well as operations within a set of institutions' (Minsky 1986a, 7). In addition, the shaping of an economy requires a definition of goals. There is no price mechanism or other invisible hand that can be relied upon to ensure optimal economic wellbeing; there is only a social system shaped by individual and collective choices (Minsky 1986a, 7-9). Further, since the economy evolves endogenously, no policy regime can provide a once-and-forall solution to economic problems: 'We cannot, in a dynamic world, expect to resolve the problems of institutional organization for all time’ (Minsky 1986a, 7, 333).

Minsky’s theory of U.S. capitalist development traces the American economy through a series of stages. The most recent transition involves the shift from managerial capitalism, ushered in by the New Deal, to money-manager capitalism, which Minsky believed had emerged in the early 1980s. According to this theory, U.S. capitalism evolved in the decades after World War II from a form driven by corporate executives to one controlled by managers of pensions, mutual funds and other institutional investors, who endeavor to maximize the value of the assets they manage (Minsky 1990; 1993; 1996). The theory can be seen as an extension of analyses of U.S. economic and industrial development found in both Veblen and Commons (Whalen 2001; 2008d).

\section{Contemporary PKI}

Although Minsky did not live to see the Asian financial crisis of the late 1990s, the dot-com era bubble and bust, or the current global financial crisis and economic downturn, other scholars continue to apply and build on the foundation he left behind. For example, a 1998 essay by Jan Kregel used Minsky’s ideas to diagnose and prescribe policies for the Asian crisis at a time when mainstream economists were admitting they had little to offer (Kregel 1998). ${ }^{5}$ In the wake of the 
'irrational exuberance' and subsequent economic difficulties that greeted the start of the new millennium, Zalewski (2002) applied the notion of money-manager capitalism to explain rising U.S. retirement insecurity; Wolfson (2002) extended Minsky's theory of financial crises to the international economy; and Wray (2002), Whalen (2002) and Rima (2002) provided additional applications and extensions. More recent contributions to the literature have been offered by Jameson (2004), Thabet (2006), Niggle (2006), Kaboub (2007), Tymoigne (2007), Wray (2008), Whalen (2008a; 2008b; 2008c) and Todorova (2009).

The economic contributions of Minsky and other institutionalists are products of careers devoted to understanding economic performance through time. In contrast, conventional economists have sought to focus on how markets operate at any moment in time, without giving attention to how those markets develop over time. However, as Douglass C. North—who served as Minsky's colleague at Washington University—asked in his Nobel Prize lecture in 1993, 'How can one prescribe policies when one doesn't understand how economies develop?’ As North's lecture suggests, because neoclassical theory assumes institutions and time do not matter, that theory is 'simply an inappropriate tool' for analyzing and prescribing real-world policies (North 1994, 359).

\section{EXPLAINING THE GLOBAL FINANCIAL CRISIS}

PKI incorporates Minsky's $(1975,9)$ assumption that the 'basic path' of real-world capitalism is cyclical and Mitchell's recognition that each cycle has its own idiosyncrasies. PKI also recognizes that such idiosyncrasies are largely a product of ongoing institutional evolution. Therefore, it seems appropriate to sketch this institutionalist analysis of the current crisis by drawing attention to the underlying tendency toward financial instability and then adding institutional elements unique to the latest cycle. 


\section{Financial Instability}

From the perspective of PKI, the financial structure of our economy becomes more and more fragile over a period of prosperity. In the early stages of prosperity, enterprises in highly profitable segments of the economy are rewarded for taking on increasing amounts of debt. And their success encourages other firms to engage in similar behavior.

This pattern was certainly evident in the high-tech sector during the late 1990s and in the housing sector during the early- and mid-2000s. In fact, construction companies and contractors were not the only ones taking on more debt in the 2000s. Homebuyers were also taking on more debt as the housing market began heating up, in part because interest rates were low and the stock market had become less attractive in the wake of the dot-com boom and bust. While it had long been customary for U.S. homebuyers to make a 20-percent down payment on a home, 42 percent of first-time home purchasers and 13 percent of buyers who were not first-time purchasers put no money down to acquire homes in the mid-2000s (Baker 2009a; Max 2005; Irwin 2005). ${ }^{6}$

In retrospect, it seems that enterprises and homebuyers should have resisted the impulse toward increasing indebtedness, but the incentives at the time were just too great. As Gary Dymski and Robert Pollin explain in a 1992 essay, nobody in a robust sector of the economy wants to be left behind due to underinvestment:

Even if market participants did have full knowledge of the Minsky model, and were aware that financial crises will occur at some point, that would still not enable them to predict when the financial crisis will occur. In the meantime, aggressive firm managers and bank loan officers will be rewarded for pursuing profitable opportunities and gaining competitive advantages. Cautious managers, operating from the understanding that boom 
conditions will end at some uncertain point, will be penalized when their more aggressive competitors surpass their short-run performance (Dymski and Pollin 1992, 45). ${ }^{7}$

As the preceding quote indicates, lenders as well as borrowers fuel the tendency toward greater indebtedness in an expansion. The same climate of expectations that encourages borrowers to acquire more risky financial liability structures also eases lenders’ worries that new loans might go unpaid (Minsky 1975). Moreover, it is not just that borrowing and lending expand in the boom. There is also financial innovation. In fact, in a 1992 essay, Minsky wrote that bankers and other financial intermediaries are 'merchants of debt, who strive to innovate with regard to both the assets they acquire and the liabilities they market' (Minsky 1992a, 6).

The boom cannot continue forever, however; we eventually arrive at what some observers have called the 'Minsky moment' (Lahart 2007, 1). That is when it becomes clear some borrowers have become overextended and need to sell assets to make their payments. In the current crisis, early high-profile cases involved the mortgage broker Countrywide and two hedge funds run by Bear Stearns (Stempel 2007; Reckard, Douglass and Petruno 2007; Mildenberg 2008; Foley 2007). ${ }^{8}$

Then the problem spreads. Since bankers and investors hold subjective views about acceptable debt levels, once a shortfall of cash and a forced selling of assets materializes somewhere in the economy, it can lead to a widespread reassessment of how much debt or lending is appropriate. Moreover, the buildup can go on for years, but when anything goes wrong the revaluation can be sudden (Minsky 1982, 67).

When banks decide to rein in their lending, we find ourselves in a credit crunch. It is easy to think of the present economic crisis as something that began with the worldwide stock-market downturn in the autumn of 2008. In fact, though, the difficulties of 2008 were preceded by a 
credit crunch that began in the summer of 2007, and signs of trouble-traceable in large part to the ‘subprime’ mortgage market—were evident as early as March 2007 (Magnus 2007; Foley 2007; 'Timeline’ 2009).

Once a credit crunch emerges, financial difficulties are no longer confined to one sector. In fact, a crunch threatens not only business investment, but also household consumption. This means that when a sectoral bubble bursts - in the high-tech sector nearly a decade ago or in the housing sector more recently-the collapse threatens to trigger an economy-wide recession.

And that sort of recession is what the United States and much of the world now experiences. Moreover it is pretty clear the situation has gone beyond a Minsky 'moment' and is more akin to an economic 'meltdown,' at least with respect to U.S. housing, banking, and stocks. The Dow Jones industrial average, for example, fell 37 percent between April 1, 2007 and April 1, 2009 (Yahoo Finance 2009). Meanwhile, the U.S. unemployment rate rose from 4.4 percent in March 2007 to 8.5 percent in March 2009 (the latest monthly data available as of this writing), and is widely expected to continue rising through 2009 (U.S. Department of Labor 2009; 'Obama’s economic aide sees rising U.S. unemployment’ 2009).

\section{Institutional Features}

While the analysis above provides some insight into the current crisis, the picture becomes clearer when distinctive institutional features of the crisis are brought into focus. The origin of today’s economic difficulties can be traced in large part to four financial-sector innovations: unconventional mortgages, securitization, the rise of hedge funds, and the globalization of finance. The importance of these items underscores the value of two major contributions Minsky made to PKI: introduction of Schumpeter's emphasis on financial-system evolution and invention of the notion of money-manager capitalism. 
At the heart of the current financial crisis are home mortgages that deviate from the traditional U.S. home-loan arrangement, which involved a long-term loan on fixed-rate terms. Many of these unconventional—some have even called them 'exotic'—mortgages have adjustable interest rates and/or payments that balloon over time. Federal law allowed banks to issue adjustable-rate mortgages since 1982, but their use and complexity have exploded in the past decade. For example, industry experts estimate that a variant called the 'option adjustable rate mortgage’ (option ARM), which offers a low 'teaser’ rate and later resets so that minimum payments skyrocket, accounted for about 0.5 percent of all U.S. mortgages written in 2003, but close to 15 percent (and up to 33 percent in many U.S. communities) in 2006. More precise figures are unavailable because banks have not been required to report how many option ARMs they originate (Der Hovanesian 2006).

Many of these mortgages were created to target less-creditworthy customers, including those in what the banking industry calls the subprime market (Baker 2009a). Others were marketed to people who wanted to speculate in the booming housing market, people who intended to buy and then quickly resell property. However, many unconventional loans were marketed to ordinary working families who could have handled conventional mortgages (Marks 2008).

Unfortunately, it was clear from the outset that many of these exotic mortgages could never be paid back. (For an eye-opening look at the aggressive marketing of unconventional mortgages, see Morgenson (2007).) But why did this happen? Why did the mortgage market evolve in this dangerous direction?

This is where securitization comes into the picture. Securitization is simply the bundling of loans—which can include auto loans, student loans, accounts receivable, and, of course, mortgages_-and the subsequent selling of bundle shares to investors. In the mid-1980s, Minsky 
returned home from a conference sponsored by the Federal Reserve Bank of Chicago and wrote that securitization was emerging as a key, new financial innovation. 'That which can be securitized, will be securitized,' he wrote (Minsky 1990, 64). He was right, but way ahead of his time. Securitization of mortgages exploded onto the scene in the past decade.

After the dot-com bubble burst in 2001, housing in the United States looked like a safer and more attractive investment than ever to many Americans, especially with low interest rates in place due to Federal Reserve policy. Still, returns on conventional mortgages were too mundane to satisfy the aims of most money managers. As a result, what Minsky and Schumpeter might have called the 'financial-innovation machine' turned its attention to housing and shifted in to high gear.

Securitization of mortgages meant that home loan originators could be less concerned about the creditworthiness of borrowers than in the past. Thus, they had an incentive to steer customers toward the most profitable types of mortgages, even if they were the riskiest (which, of course, they were) (Der Hovanesian 2006). The result was the explosive growth in option ARMs and in 'no money down' and 'no documentation (of income)' loans. Minsky warned of all this in 1992, when he observed that securitization means mortgage originators are rewarded as long as they avoid 'obvious fraud' (Minsky 1992b, 22-23). ${ }^{9}$

Securitization worked like magic upon risky mortgages. Instead of 'garbage in, garbage out,' risky loans went into the process, but out came bundles that received high credit ratings from agencies like Standard and Poors. According to Christopher Huhne, a member of the British Parliament and former rating-agency economist, part of the challenge of rating the bundles was 'that financial markets fall in love with new things, with innovations, and the [important] thing 
about new things is that it is very difficult to assess the real riskiness of them because you don't have a history by definition’ (Huhne 2007).

Another problem is that the rating agencies do not verify the information provided by mortgage issuers. Instead, they base their decisions on information received from intermediaries that, as Minsky put it, 'do not hazard any of their wealth on the long term viability of the underlying [loans]’ (Minsky 1992b, 23).

Moreover, there are so many middlemen in the mortgage securitization game, including a number permitted to operate in a largely unregulated manner, that no one person or organization can be easily assigned blame in the event of default. The chain between the borrower and the investor includes realtors, home appraisers, mortgage brokers, mortgage originators, investment banks that bundled the mortgages, agencies that rated the bundles, and even companies (like American International Group) that insured many of the bundles (Whalen 2008b, 235). ${ }^{10}$

Trillions of dollars worth of mortgage-backed securities were bundled and sold as shares to investors. In late 2008, Fannie Mae and Freddie Mac alone held \$4.1 trillion (Lanman and Kopecki 2008).

Many of the underlying mortgages are now in foreclosure or are headed there. In 2008, 2.3 million U.S. homes went into foreclosure, up 81 percent from 2007 and 225 percent from 2006 (RealtyTrac 2009). There were another 290,000 filings in February 2009 (the most recent period for which data are available as this chapter is being written), up 6 percent from the previous month (El Nasser 2009).

Mortgage delinquencies are also up sharply. In February 2009, 7 percent of U.S. homeowners with mortgages were at least 30 days late on their loans, an increase of more than 
50 percent from a year earlier. Among subprime borrowers, that month's delinquency rate was 39.8 percent (Chernikoff 2009). (Again, these are the latest available figures.)

There has been much public discussion over the past year or so in the United States about reckless homebuyers, but mortgage seekers could not and did not bring the economy to its knees on their own. Behind both the exotic home loans and mortgage securitization is money-manager capitalism. As Minsky stressed at a pair of professional conferences in the late 1980s and early 1990s, there is a symbiotic relationship 'between the growth of securitization and managed money;' fund managers 'have outgrown the orthodox high quality stocks and bond portfolios of fiduciaries’ (Minsky 1990, 71; 1992c, 32).

From the perspective of PKI, the economic participants most responsible for bringing down the economy are hedge funds and other investment funds, investment banks, and other financial institutions. Looking at hedge funds offers a glimpse at what happened. Although the following discussion focuses on hedge funds because they are a relative newcomer to the scene and have become infamous for operating beyond the reach of much government regulation, the investment banks and other institutions played a similar role.

Some of the biggest purchasers of securitized mortgages have been hedge funds. The first of these funds were established in the first few decades after World War II for the purpose of seeking absolute returns (rather than beating a benchmark stock-market index). They were indeed 'hedged' funds, which sought to protect principal from financial loss by hedging investments through short selling or other means. The number of hedge funds and the assets under their management expanded in the 1990s and grew even more rapidly in the 2000s. At the same time, these assets became increasingly concentrated at the top10 firms and funds became more diverse in terms of the strategies their managers employed. In mid-2008, the Alternative 
Investment Management Association estimated that the world's hedge funds (based primarily in the United States) were managing \$2.5 trillion, though it acknowledged that other estimates were as high as $\$ 4$ trillion (Ineichen and Silberstein 2008, 16).

The total value of assets under hedge-fund management is uncertain because such funds are typically restricted to wealthy individuals and institutional investors, which exempts them from most financial-sector reporting requirements and regulation. Taking advantage of their largely unregulated status, managers of hedge funds used their mortgage-backed securities as collateral to take out highly leveraged loans. They then purchased an assortment of financial instruments, including still more mortgage bundles. As a result, the world’s hedge funds used securitized mortgages to lay an inherently flimsy foundation for a financial 'house of cards' (Freeman 2009; Holt 2009).

The current crisis is unmistakably global. It is having economic and political ramifications on all continents ('Timeline' 2009; Whalen 2009). The trouble is even affecting unexpected places like rural China: factories in cities along that nation's coast are laying-off workers and sending them back to their villages (Lee 2009).

The global nature of the current situation would not have surprised Minsky, who stressed early on that money-manager capitalism 'is international in both the funds and the assets in funds' (Minsky 1990, 71). Looking ahead to the current crisis, Minsky wrote: 'The problem of finance that will emerge is whether the ... institutions of national governments can contain both the consequences of global financial fragility and an international debt deflation’ (Minsky 1995, 93). He worried that the United States would be unable to serve as 'the guardian angel for stability in the world economy' and stressed the need for 'an international division of responsibility for maintaining global aggregate gross profits’ (Minsky 1986d, 15; 1990, 71). 
In short, from the perspective of PKI, the global economy is now reeling from the consequences of a classic Minsky crisis. Its origins are in a housing boom fueled by rising expectations, expanding debt, and financial innovation. Then the bubble burst, creating first a credit crunch, then a broader banking and stock-market crisis, and now a recession.

The consequences have been staggering. In the housing sector, an unprecedented one in nine U.S. homes (14 million) sits vacant, while another 9.4 million are for sale (El Nasser 2009). The U.S. stock market lost an unprecedented $\$ 1.2$ trillion of value in just a single day in late September 2008 (measured by the Wilshire 5000), and for 2008 overall the Dow Jones industrial average had its worst year since 1931 (Twin 2008; Blaine 2008). Unemployment may soon hit double digits in the United States and has already reached double digits in some parts of Europe (Eurostat 2009).

Since 2007, the global banking industry has seen an unprecedented shakeout ('Timeline' 2009), but there is still uncertainty about how much more difficulty lies ahead. As the Bank for International Settlements indicated in a report released in June 2007:

Assuming that the big banks have managed to distribute more widely the risks inherent in the loans they have made, who now holds these risks, and can they manage them adequately? The honest answer is that we do not know. Much of the risk is embodied in various forms of asset-backed securities of growing complexity and opacity. They have been purchased by a wide range of smaller banks, pension funds, insurance companies, hedge funds, other funds and even individuals, who have been encouraged to invest by the generally high ratings given to these instruments (Bank for International Settlements 2007, 145). 
Warren Buffett made the point more vividly: 'You only learn who has been swimming naked when the tide goes out' (Buffett 2008, 3). Although the risks are now being laid bare, it will still be some time before the world learns the full extent of the financial exposure.

\section{TOWARD RENEWED PROSPERITY}

The current global economic situation requires a two-pronged economic-policy strategy:

recovery and reform. Beyond stabilizing the troubled financial sector and preventing the current downturn from becoming more severe, the overarching policy objective should be greater macroeconomic stability and broadly shared prosperity in the United States and abroad. The discussion below is intended to merely highlight some of the important issues and necessary steps; a comprehensive revitalization plan would require considerably more space than is available and deserves to be fashioned by a team, rather than by an individual. ${ }^{11}$

\section{Recovery}

A government strategy for recovery must have at least three components: monetary policy, fiscal policy, and financial-market policy. Each is considered in turn.

Monetary policy is on the right track. The Federal Reserve has been trying to stabilize the financial sector and the overall economy for well over a year. It has aggressively cut interest rates, allowed banks to borrow from it at nominal rates, and given banks cash in exchange for risky assets (promising to take on the risk if those assets prove worthless). The Fed has also engineered bank mergers and worked with other central banks to increase the supply of dollars worldwide. In a very short time, Fed chairman Ben Bernanke has moved a long way from the days when he was known as a proponent of inflation targeting.

Fiscal policy in the United States has also been moving in the right direction, but has been too timid. The first stimulus attempt, passed in early 2008, included $\$ 100$ billion in tax rebates 
and helped prop up consumer spending (Broda and Parker 2008), but the bill also included tens of billions in less stimulative business tax cuts. More recently, President Barack Obama signed into law a stimulus package totaling $\$ 787$ billion over two years. However, Paul Krugman was probably correct when he suggested the package should have been twice as big and even more tilted toward spending (as opposed to tax cuts), especially since recent data revisions show that fourth-quarter U.S. gross domestic product fell by 6.3 percent, not 4.0 percent as reported originally (Earnshaw 2009; Krugman 2009a). ${ }^{12}$

Financial-market policy at the U.S. Treasury Department, however, has been woefully inadequate. The Troubled Asset Relief Program, more commonly known as the $\$ 700$ billion Wall St. Bailout, seemed designed to clean up bank balance sheets by purchasing their bad assets. Instead, the Treasury was soon writing banks checks and buying large quantities of bank stocks. The underlying problem of the 'toxic' assets remained unresolved, banks remained reluctant to lend, and much of the added liquidity was transformed into bank stock dividends.

The Treasury’s latest plan, a ‘public-private partnership’ that creates a market for troubled assets with government loans and guarantees, is not much better. The plan offers what Joseph E. Stiglitz calls a 'win-win-lose proposal: the banks win, investors win—and taxpayers lose.' He argues the plan encourages investors to bid high in that market and socializes the losses that are likely to follow. In attempting to account for this proposal, Stiglitz writes: 'Perhaps it's the kind of Rube Goldberg device that Wall Street loves_clever, complex and nontransparent, allowing huge transfers of wealth to the financial markets’ (Stiglitz 2009).

Minsky, who admired how the administration of President Franklin D. Roosevelt closed insolvent banks and assisted solvent ones during the Great Depression, would have almost certainly called for a more hands-on sorting-out of the financial mess by means of bank 
restructuring. Today, Krugman (2009b; 2009c), Dean Baker (2009b), and James K. Galbraith (2009) call for similar action. As Galbraith writes, 'If the subprime securities are truly trash, most of the big banks are troubled and some are insolvent. The FDIC should put them through receivership, get clean audits, install new management, and begin the necessary shrinkage of the banking system with the big guys, not the small ones’ (Galbraith 2009). The Obama administration recently ordered federal regulators to conduct 'stress tests' to gauge the condition of the nation's banks. As a next step, the receivership approach makes more sense than creation of a government-subsidized market for toxic assets.

Another aspect of financial-market policy that needs attention is home mortgages. Throughout 2008, the United States largely avoided addressing the unaffordable mortgages that are at the heart of the current problem (Marks 2008). The Obama administration has been encouraging the financial industry to voluntarily restructure those loans, but industry pressure has made many in the nation's capital reluctant to require it. For example, federal legislators have so far refused to let bankruptcy judges insist on home loan restructuring, despite the fact that judges can demand a restructuring of all loans except the mortgage on a homeowner's residence (legislation is stalled in the U.S. Senate as of this writing).

\section{Reform}

Looking beyond the current downturn, a reform agenda must include stricter regulation and supervision of the financial system, a national commitment to the challenges facing America's working families, and U.S. participation in efforts that promote international economic stability and job creation.

Minsky believed that those responsible for government regulation and supervision of the financial system were in a 'never-ending struggle' with financial markets (Minsky, quoted in 
Phillips 1997, 512). As he wrote in 1986, 'After an initial interval, the basic disequilibrating tendencies of capitalist finance will once again push the financial structure to the brink of fragility’ (Minsky 1986a, 333). Still, he always believed it was necessary for regulators to continue the struggle. Today's institutionalists hold the same view.

Greater industry transparency, more rigorous bank examinations, and broader regulatory oversight would be a good place to start. If policymakers had better information about the extent to which financial institutions were making use of option ARMs and other exotic instruments, perhaps at least a few would have more aggressively sought to address the mounting problem. It also seems appropriate to revive Minsky's notion of a cash-flow approach to bank examinations, which is 'designed to use the examination process to generate information on not only the liquidity and solvency of particular institutions, but also on threats, if any, to the stability of financial markets' (Minsky, quoted in Phillips 1997, 513). Similarly, mortgage brokers, hedge funds, and other institutions that have gained increasing importance in the past decade deserve greater scrutiny from financial-system regulators. ${ }^{13}$ In light of the current economic crisis, stricter oversight of securitization and other recent financial innovations are clearly overdue, but the additional need is for regulators to be on the lookout for future innovations in an effort to head-off future crises before they occur.

At the very least, the U.S. government should not block state efforts designed to protect their citizens from gaps in federal law. Today, most Americans know about the 2008 Valentine’s Day in Washington that cost former New York Governor Eliot Spitzer his job, but of greater national importance was his guest column that appeared in The Washington Post that day. It described how the federal government stopped states from cracking down on predatory lending practices. As Sptitzer's essay documents, 'Not only did the Bush administration do nothing to protect 
consumers, it embarked on an aggressive and unprecedented campaign to prevent states from protecting their residents from the very problems to which the federal government was turning a blind eye. ... The tale is still unfolding, but when the dust settles, [the Bush administration] will be judged as a willing accomplice to the lenders who went to any lengths in their quest for profits’ (Spitzer 2008).

In the age of managerial capitalism, it may have been sufficient to focus on full employment, low inflation and steady economic growth. In the age of money-manager capitalism, these goals are still important, but the challenges facing America’s working families require more direct attention as well. Americans, like citizens elsewhere around the world, want the opportunity to develop and utilize their talents and to increase their standard of living in the process. They also want the prospect of an even better life for their children.

Unfortunately, rising worker insecurity is the flipside of money-manager capitalism. Under pressure from money managers, corporate executives have largely put aside the employeremployee social contract of the New Deal and the early decades following World War II. They have moved increasingly toward treating labor as just another 'spot market' commodity (Minsky 1996; Minsky and Whalen 1996-1997; Whalen 1997; Whalen 2008a).

Thus, the economic challenges facing the United States extend far beyond stabilizing the financial system and preventing a long and deep recession. The nation needs to spur the growth of domestic jobs that pay family-supporting wages and to ensure that Americans have access to the education and training such jobs require (Marshall 2010; Glover and King 2010). It needs to find a way to promote partnerships between workers and managers, so companies can compete on the basis of innovation, quality and customer service, rather than by outsourcing jobs or slashing wages and benefits. It needs to provide adjustment assistance to workers displaced by 
international trade (including service workers excluded from some existing benefits programs) and public-service employment to those unable to find private-sector work. And it needs healthcare reform, retirement-system reform, and labor-law reform to address medical insecurity, retirement insecurity, and the insecurity of workers who seek to exercise their legal right to engage in union organizing and collective bargaining (Whalen 2008a; 2008f). ${ }^{14}$

Finally, pursuit of greater economic stability and broadly shared prosperity cannot end at the borders of the United States. Americans must be active in helping to fashion international institutions that not only contain global financial instability, but also enhance labor rights and promote job growth. According to Stiglitz,

During my three years as chief economist of the World Bank, labor market issues were looked at through the lens of neoclassical economics. 'Wage rigidities'—often the fruits of hard-fought bargaining — were thought part of the problem facing many countries. A standard message was to increase labor market flexibility. The not-so-subtle subtext was to lower wages and lay off unneeded workers (Stiglitz, quoted in Komisar 2000).

He concludes, 'They had a strategy for job destruction. They had no strategy for job creation’ (Stiglitz, quoted in Komisar 2000). Institutionalists in the United States need to work with likeminded economists in other nations to develop that missing strategy.

\section{CONCLUSION: STANDING ON THE SHOULDERS OF GIANTS}

Minsky used to say we should stand on the shoulders of giants to better understand the economy; PKI seeks to do just that. Veblen, Mitchell, Commons, Keynes and Schumpeter provided a foundation. Minsky and other post-World War II post-Keynesian institutionalists built upon the foundation. The present generation is now applying and adapting the inherited framework as a way to interpret and address the current situation. If PKI is successful, it will leave the next 
generation both a more prosperous global economy and a more evolutionary and institutionally grounded economic science.

\section{NOTES}

1. Institutionalists recognize system tendencies, but are unwilling to assume self-reinforcing or self-regulating forces dominate a priori. It all depends on the social institutions. See, for example, Myrdal (1977).

2. For a discussion of what is 'general' in The General Theory, see Crotty (1990).

3. While Minsky accepted the 'post Keynesian' label, he was not entirely comfortable with it. A key reason underscores his connection to institutionalism: 'He wanted to distance himself from a tendency in post Keynesian economics to push institutions into the background in order to develop 'general theories’’ (Papadimitriou and Wray 1998, 201).

4. According to Mitchell, 'Business history repeats itself, but always with a difference’ (Mitchell 1941, ix). For this reason, he stressed that 'history and theory supplement each other' (Mitchell 1927, 57).

5. In an October 1998 essay published in The New Republic, Paul Krugman wrote the following regarding the Asian financial crisis: 'Suppose that you were to buy a copy of the best-selling textbook on international economics. What would it tell you about how to cope with such a sudden loss of confidence by international investors? Well, not much. (Trust me--I'm the coauthor of that textbook.)' (Krugman 1998, 23).

6. Homeowners were also able to fuel a consumption boom by taking on even more debt. That is because rising home prices encouraged banks to increase customers' credit-card limits and to heavily promote home-equity loans (Chu and Acohido 2008; Story 2008). 
7. Dymski and Pollin add: 'When boom conditions do end, aggressive managers will already have been promoted, while cautious managers will have been demoted, if not dismissed. Moreover, during the slump, all aggressive managers will fail together, so no single individual will be singled out for blame. This is in contrast to the boom, where the miscalculating cautious will have been isolated' (Dymski and Pollin 1992, 45).

8. Of course, Bear Stearns itself was to be a casualty of the crisis in early 2008.

9. Here are some figures that indicate the magnitude of U.S. mortgage securitization: in early 2007, about 65 percent of mortgages were being turned into bonds via securitization, up from 40 percent in 1990; and, in the years 2004-2006, nearly \$100 billion per year in option ARMs were sold to investors (Pittman 2007; Der Hovanesian 2006).

10. Mortgage brokers, who operate without much government regulation, accounted for 80 percent of all U.S. mortgage originations in 2006, double their share a decade earlier (Der Hovanesian 2006).

11. The focus of this discussion is on the United States, not merely because the economic trouble originated there, but also because this author's training and experience have been heavily oriented toward studying and addressing the functioning of that economy.

12. Another reason for suggesting the 2009 stimulus was too timid is that the first-year tax-cut multipliers estimated by Christine Romer and Jared Bernstein were considerably below 1.0 (Romer and Bernstein 2009, 12). Thus, modifying the package in the direction of tax cuts (to ensure passage) seemed ill advised from a macroeconomic perspective.

13. The use of leverage by hedge funds and the writing of no documentation home loans are among the practices in greatest need of regulatory attention. 
14. To address the challenges facing America's working families, the Obama administration has created a Middle Class Task Force, headed by Vice President Joe Biden. Its goals suggest an awareness of the issues discussed above ('About the Task Force' 2009).

\section{REFERENCES}

'About the Task Force,' The White House Blog (January 30, 2009), http://www.whitehouse.gov/blog_post/about_the_task_force_1/ (accessed April 13, 2009).

Atkinson, Glen and Theodore Oleson Jr. 1998. 'Commons and Keynes: their assault on laissez faire,' Journal of Economic Issues 32 (4), 1019-1030.

Bank for International Settlements. 2007. 77th Annual Report. Basel, Switzerland: Bank for International Settlements Press and Communications.

Baker, Dean. (2009a), ‘The economic crisis: how we got here,' PowerPoint Presentation. Labor and Employment Relations Association Annual Meeting. January 3. San Francisco, California. . (2009b), ‘Geithner’s plan will tax Main Street to make Wall Street Richer,' The Huffington Post (March 30), http://www.huffingtonpost.com/dean-baker/geithners-plan-willtax-m_b_181021.html (accessed April 13, 2009).

Blaine, Charley. (2008), ‘Wall Street says ‘good riddance!’ to 2008,' MSN Money (December 31), http://articles.moneycentral.msn.com/Investing/Dispatch/worst-year-since-1931123108.aspx (accessed April 13, 2009).

Brazelton, W. Robert. (1981), 'Post Keynesian economics: an institutional compatibility,’ Journal of Economic Issues 15 (2), 531-542.

Buffett, Warren E. (2008), Letter to shareholders, Berkshire Hathaway Inc., 2007 Annual Report. 
Chase, Richard X. 1975. 'Keynes and U.S. Keynesianism: A Lack of Historical Perspective and the Decline of the New Economics,' Journal of Economic Issues 9 (3), 441-461.

Chernikoff, Helen. (2009), 'U.S. mortgage delinquencies up 50 percent,' Reuters UK, http://uk.reuters.com/article/economyNews/idUKTRE5374LT20090408 (accessed April 13. 2009).

Chu, Kathy and Byron Acohido. (2008), 'How rising home values, easy credit put your finances at risk,' USA Today (December 15), http://www.usatoday.com/money/perfi/credit/2008-0617-credit-card-trap_N.htm

Commons, John R. 1922. 'Unemployment prevention,’ American Labor Legislation Review 12 (1) $15-24$. . (1934), Myself. New York: Macmillan. . (2008), 'Reasonable Value,' in Warren J. Samuels (ed.), Research in the History of Economic Thought and Methodology, Volume 26-B, Bingley, UK: Emerald, pp. 239-307. Crotty, James R. (1990), 'Keynes on the stages of development of the capitalist economy: the institutional foundation of Keynes’s methodology,' Journal of Economic Issues 24 (3), 761780.

Der Hovanesian, Mara. (2006), ‘Nightmare mortgages,’ BusinessWeek (September 11), http://www.businessweek.com/magazine/content/06_37/b4000001.htm (accessed April 13, 2009).

Dillard, Dudley. (1980), 'A monetary theory of production: Keynes and the institutionalists,' Journal of Economic Issues 14 (2), 255-273. . (1987), 'Money as an institution of capitalism,' Journal of Economic Issues 21 (4), 16231647. 
Dugger, William M. (1996), ‘Redefining economics: from market allocation to social provisioning,” in Charles J. Whalen (ed.), Political Economy for the $21^{\text {st }}$ Century: Contemporary Views on the Trend of Economics, Armonk, New York: M.E. Sharpe, pp. 3143.

Dymski, Gary and Robert Pollin. (1992), 'Minsky as hedgehog: the power of the Wall Street paradigm,' in Steven Fazzari and Dimitri B. Papadimitriou (eds.), Financial Conditions and Macroeconomic Performance: Essays in Honor of Hyman P. Minsky, Armonk, New York: M.E. Sharpe, pp. 27-61.

Earnshaw, Aliza. (2009), ‘Krugman: stimulus needs to be twice as big,’ Portland Business Journal (February 2), http://www.bizjournals.com/portland/stories/2009/01/26/daily68.html (accessed April 13, 2009).

El Nasser, Haya. (2009), 'Open house anyone? 1 in 9 homes sit empty,' USA Today, http://www.usatoday.com/money/economy/housing/2009-04-09-vacanthomes_N.htm (accessed April 13, 2009).

Eurostat. (2009), ‘Euro area unemployment up to 8.5 percent,’ News Release, Eurostat Euroindicators (April 1), downloaded from http://ec.europa.eu/eurostat/euroindicators (accessed April 13, 2009).

Fazzari, Steven and Hyman P. Minsky. (1984), 'Domestic monetary policy: if not monetarism, what?' Journal of Economic Issues 18 (1), 101-116.

Freeman, James. (2009), 'How the money vanished,' The Wall Street Journal (March 6), http://online.wsj.com/article/SB123630340388147387.html (accessed April 13, 2009). 
Foley, Stephen. (2007), Anatomy of a credit crunch,' The (London) Independent (July 27), http://findarticles.com/p/articles/mi_qn4158/is_20070727/ai_n19447440/?tag=content;col1 (accessed April 13, 2009).

Foster, John Fagg. (1981a), 'Economics,’ Journal of Economic Issues 15 (4), 857-867. . (1981b), 'Understandings and misunderstandings of Keynesian economics,' Journal of Economic Issues 15 (4), 949-957.

Galbraith, James K. (2009), 'The Geithner plan won’t work,' The Daily Beast (March 24), http://www.thedailybeast.com/blogs-and-stories/2009-03-24/the-geithner-plan-wontwork/full/ (accessed April 13, 2009).

Glover, Robert W. and Christopher T. King. (2010), 'Sectoral Approaches to Workforce Development: Toward an Effective U .S. Labor Market Policy,' in Charles J. Whalen (ed.), Human Resource Economics and Public Policy: Essays in Honor of Vernon M. Briggs Jr., Kalamazoo, Michigan: W.E. Upjohn Institute for Employment Research, forthcoming. Heilbroner, Robert. (1996), 'Economics in the twenty-first century,' in Charles J. Whalen (ed.), Political Economy for the $21^{\text {st }}$ Century: Contemporary Views on the Trend of Economics, Armonk, New York: M.E. Sharpe, pp. 265-274.

Holt, Christopher. (2009), 'A graphical look at hedge fund leverage,' Seeking Alpha (March 8), http://seekingalpha.com/article/124783-a-graphical-look-at-hedge-fund-leverage.

Huhne, Christopher. 2007. Comments on Credit Rating Agencies and the U.S. Credit Crunch. World Business Review, BBC World Service (September 1).

Ineichen, Alexander and Kurt Silberstein. (2008), AIMA's roadman to hedge funds, London: The Alternative Investment Management Association. 
Irwin, Gloria. (2005), 'No money down gains more buyers,' Akron Beacon Journal (July 31), http://www.policymattersohio.org/media/ABJ_No_money_down_gains_more_buyers_2005_ 0731.htm (accessed April 13, 2009).

Jameson, Kenneth P. (2004), 'Dollarization in Ecuador: a post-Keynesian institutionalist analysis,' Working Paper Number 2004-5, Department of Economics, University of Utah.

Kaboub, Fadhel. (2007), 'Institutional adjustment planning for full employment,' Journal of Economic Issues 41 (2), 495-502.

Keller, Robert R. (1983), ‘Keynesian and institutional economics: compatibility and complementarity,' Journal of Economic Issues 17 (4), 1087-1095.

Keynes, John Maynard. (1927), Letter to John R. Commons, April 26. Reproduced in John R. Commons Papers, microfilm edition, reel 4. Madison, Wisconsin: State Historical Society of Wisconsin. . (1935), ‘A self-adjusting economic system?’ The New Republic 82 (1055): 35-37. . (1972), ‘Am I a liberal?’ in Donald Moggridge (ed.), The Collected Writings of John Maynard Keynes, Volume 9, Essays in Persuasion, London: Macmillan, pp. 295-311. Based on an address delivered in United Kingdom during the summer of 1925. . (1981), 'The economic transition in England,' in Donald Moggridge (ed.), The Collected Writings of John Maynard Keynes, Volume 19, The Return to Gold and Industrial Policy, New York: Macmillan, pp. 438-442. Based on an address delivered in Moscow, September 1925.

Komisar, Lucy. (2000), 'Interview with Joseph Stiglitz,' The Progressive (June), http://www.progressive.org/0901/intv0600.html (accessed April 13, 2009). 
Kregel, Jan. (1998), 'Yes ‘it’ did happen again: A Minsky crisis in Asia,' Working Paper

Number 234, The Levy Economics Institute of Bard College.

Krugman, Paul. (1998), ‘The confidence game,' The New Republic 219 (14), 23-25. . (2009a), 'Stimulus arithmetic (wonkish but important),' The New York Times (January 6), http://krugman.blogs.nytimes.com/2009/01/06/stimulus-arithmetic-wonkish-but-important/ (accessed April 13, 2009). . (2009b), 'Despair over financial policy,' The New York Times (March 21), http://krugman.blogs.nytimes.com/2009/03/21/despair-over-financial-policy/ (accessed April 13, 2009). . (2009c), ‘Geithner plan arithmetic,’ The New York Times (March 23), http://krugman.blogs.nytimes.com/2009/03/23/geithner-plan-arithmetic/ (accessed April 13, 2009).

Lahart, Justin. (2007), 'In time of tumult, obscure economist gains currency,' The Wall Street Journal (August 8), 1.

Lanman, Scott and Dawn Kopecki. (2008), 'Fed commits $\$ 800$ billion more to unfreeze lending,' Bloomberg.com (November 25), http://www.bloomberg.com/apps/news?pid=20601103\&refer=us\&sid=a.IQxmdJnJMc (accessed April 13, 2009).

Lee, Don. (2009), 'Migrant factory workers at a loss as China’s economy slumps,' Los Angeles Times (January 23), http://articles.latimes.com/2009/jan/23/business/fi-chinamigrant23 (accessed April 13, 2009).

Lewisohn, Sam A., Ernest Gallaudet Draper, John R. Commons, and Don D. Lescohier. (1925), Can Business Prevent Unemployment? New York: Alfred A. Knopf. 
Magnus, George. (2007), 'The credit cycle and liquidity: have we arrived at a Minsky moment?' Economic Insights—By George, UBS Investment Research, London (March).

Marks, Bruce. (2008), 'Bailout must address the foreclosure crisis,' The Boston Globe (September 24), http://www.boston.com/bostonglobe/editorial_opinion/oped/articles/2008/09/24/bailout_must _address_the_foreclosure_crisis/(accessed April 13, 2009).

Marshall, Ray. (2010), 'Learning Systems for a Globalized Economy: Do Americans Face Tough Choices or Tough Times?’ in Charles J. Whalen (ed.), Human Resource Economics and Public Policy: Essays in Honor of Vernon M. Briggs Jr., Kalamazoo, Michigan: W.E. Upjohn Institute for Employment Research, forthcoming.

Max, Sarah. (2005), 'Risky real estate moves,' CNNMoney.com (April 4), http://money.cnn.com/2005/03/07/real_estate/financing/riskyloans/index.htm (accessed April 13, 2009).

Mildenberg, David (2008), 'Bank of America to acquire Countrywide for \$4 billion,' Bloomberg.com (January 11), http://www.bloomberg.com/apps/news?pid=20601087\&refer=home\&sid=aCbUSVliDIKQ (accessed April 13, 2009).

Minsky, Hyman P. (1975), John Maynard Keynes, New York: Columbia University Press. . (1982), Can 'it' happen again? Essays on instability and finance, Armonk, New York:

M.E. Sharpe. . (1986a), Stabilizing an Unstable Economy, New Haven: Yale University Press. . (1986b), 'The evolution of financial institutions and the performance of the economy,' Journal of Economic Issues 20 (2), 345-353. 
. (1986c), 'Money and crisis in Schumpeter and Keynes,' in Hans-Jurgen Wagener and

Jan W. Drukker (eds.), The Economic Law of Motion of Modern Society: A Marx-Keynes-

Schumpeter Centennial, Cambridge, UK: Cambridge University Press, pp. 112-122.

. (1986), Global consequences of financial deregulation,' The Marcus Wallenberg Papers

on International Finance 2 (1), 1-19.

. (1990), 'Schumpeter: finance and evolution,' in Arnold Heertje and Mark Perlman (eds.),

Evolving Market Technology and Market Structure: Studies in Schumpeterian Economics,

Ann Arbor: The University of Michigan Press, pp. 51-74.

. (1992a), ‘The financial instability hypothesis,' Working Paper Number 74, The Levy

Economics Institute of Bard College.

. (1992b), "The capital development of the economy and the structure of financial

institutions,' Working Paper Number 72, The Levy Economics Institute of Bard College. . (1992), 'Reconstituting the United States’ financial structure: some fundamental issues,'

Working Paper Number 69, The Levy Economics Institute of Bard College.

. (1993), 'Schumpeter and finance,' in Salvatore Biasco, Alessandro Roncaglia, and

Michele Salvati (eds.), Market and Institutions in Economic Development: Essays in Honour

of Paulo Sylos Labini, New York: St. Martin’s Press, pp. 103-115.

. (1996), 'Uncertainty and the institutional structure of capitalist economies,' Journal of

Economic Issues 30 (2), 357-368.

Minsky, Hyman P. and Charles J. Whalen. (1996-97), 'Economic insecurity and the institutional prerequisites for successful capitalism,' Journal of Post Keynesian Economics 19 (2), 155170.

Mitchell, Wesley C. 1913. Business Cycles. Berkeley, California: University of California Press. 
. (1927), Business Cycles: The Problem and Its Setting. New York: National Bureau of

Economic Research.

. (1941), Business Cycles and Their Causes, Berkeley, California: University of California

Press.

Morgenson, Gretchen. (2007), 'Inside the Countrywide lending spree,’ The New York Times (August 26), http://www.nytimes.com/2007/08/26/business/yourmoney/26country.html?hp (accessed April 13, 2009).

Myrdal, Gunnar. (1977), ‘The meaning and validity of institutional economics,' in Rolf Steppacher, Brigitte Zogg-Walz and Hermann Hatzfeldt (eds.), Economics in Institutional Perspective: Memorial Essays in Honor of K. William Kapp, Lexington, Massachusetts: D.C. Heath, pp. 3-10.

North, Douglass. (1994), 'Economic performance through time,' The American Economic Review 84 (3), 359-368.

Niggle, Chris. (2006), 'Evolutionary Keynesianism: A synthesis of institutionalist and post Keynesian macroeconomics,' Journal of Economic Issues 40 (2), 405-412.

'Obama’s economic aide sees rising U.S. unemployment,' AFP [Agence France-Presse] (April 9, 2009), http://www.google.com/hostednews/afp/article/ALeqM5g2urt_Wnm7TePnhznr5dLcBYY1w (accessed April 13, 2009).

Papadimitriou, Dimitri and L. Randall Wray. (1998), 'The economic contributions of Hyman Minsky: varieties of capitalism and institutional reform,' Review of Political Economy, 10 (2), 199-225.

Peterson, Wallace C. (1977), 'Institutionalism, Keynes and the real world,' Journal of Economic Issues 11 (2), 201-221. 
. (1987), 'Macroeconomic theory and policy in an institutionalist perspective,' Journal of Economic Issues 21 (4), 1587-1621.

Phillips, Ronnie J. (2007), 'Rethinking bank examinations: a Minsky approach,’ Journal of Economic Issues 31 (2), 509-516.

Pittman, Mark. (2007), 'Subprime bondholders may lose \$75 billion from slump,' Bloomberg.com (April 24), http://www.bloomberg.com/apps/news?pid=20601087\&sid=aq3flDbwBCbk\&refer=home (accessed April 13, 2009).

Ramstad, Yngve. (1985), 'Comments on Adams and Brock paper,' Journal of Economic Issues 19 (2), 507-511.

RealtyTrac Staff. (2009), ‘Foreclosure activity increases 81 percent in 2008,' RealtyTrac.com, http://www.realtytrac.com/ContentManagement/pressrelease.aspx?ChannelID=9\&ItemID=5 681 (accessed April 13, 2009).

Reckard, E. Scott, Elizabeth Douglass, and Tom Petruno. 2007. "BofA invests $\$ 2$ billion in Countrywide,” Los Angeles Times (August 23), C1, http://articles.latimes.com/2007/aug/23/business/fi-mortgage23 (accessed April 13, 2009).

Romer, Christina and Jared Bernstein. (2009), The Job Impact of the American Recovery and Reinvestment Plan. Washington, DC: Presidential Transition Team. January 9.

Spitzer, Eliot. (2008), 'Predatory Lenders’ Partner in Crime,' The Washington Post, http://www.washingtonpost.com/wp-dyn/content/article/2008/02/13/AR2008021302783.html (accessed April 13, 2009).

Stempel, Jonathan. (2007), ‘Countrywide uses \$11.5B credit line to pay for loans,' USA Today (August 16), http://www.usatoday.com/money/economy/housing/2007-08-15-countrywide- 
stock_N.htm (accessed April 13, 2009).

Stiglitz, Joseph E. 'Obama’s Ersatz Capitalism,’ The New York Times (March 31) http://www.nytimes.com/2009/04/01/opinion/01stiglitz.html (accessed April 13, 2009).

Story, Louise. (2008), 'Home equity frenzy was a bank ad come true,' The New York Times (August 15), http://www.nytimes.com/2008/08/15/business/15sell.html (Accessed April 13, 2009).

Thabet, Slim. (2006), ‘Understanding the link among uncertainty, instability, and institutions and the need for stabilization policies: towards a synthesis between post Keynesian and institutional economics,' in L. Randall Wray and Mathew Forstater (eds.), Money, Financial Instability and Stabilization Policy, Cheltenham, UK: Edward Elgar, pp. 85-103.

'Timeline: credit crunch to downturn,' BBC News (April 3, 2009), http://news.bbc.co.uk/2/hi/business/7521250.stm (accessed April 13, 2009).

Todorova, Zdravka. (2009), Money and Households in a Capitalist Economy: A Gendered Post Keynesian - Institutional Analysis. Cheltenham, UK: Edward Elgar.

Twin, Alexandra, (2008), 'Stocks crushed,' CNNMoney.com (September 29), http://money.cnn.com/2008/09/29/markets/markets_newyork/index.htm?cnn=yes (accessed April 13, 2009).

Tymoigne, Eric. (2007), 'Improving financial stability: uncertainty versus imperfection,’’ Journal of Economic Issues 41 (2), 503-510.

U.S. Department of Labor. (2009), ‘Employment Situation Summary.’ Economic News Release, Bureau of Labor Statistics, http://www.bls.gov/news.release/empsit.nr0.htm (accessed April 13, 2009). 
Veblen, Thorstein B. (1898), 'Why is economics not an evolutionary science?’ The Quarterly Journal of Economics 12 (4), 373-397.

. (1904), The Theory of Business Enterprise. New York: Charles Scribner’s Sons. . (1923), Absentee Ownership and Business Enterprise in Recent Times: The Case of America. New York: B. W. Huebsch.

Whalen, Charles J. (1993), 'Saving capitalism by making it good: the monetary economics of John R. Commons,' Journal of Economic Issues 27 (4), 1155-1179. . (1996), 'The Veblen-Commons award: Hyman P. Minsky,' Journal of Economic Issues 30 (2), 353-355. • (1997), 'Money manager capitalism and the end of shared prosperity,' Journal of Economic Issues 31 (2), 517-526.

. (2001), 'Integrating Schumpeter and Keynes: Hyman Minsky’s theory of capitalist development,' Journal of Economic Issues 35 (4), 805-823.

. (2002), 'Money manager capitalism: still here, but not quite as expected,' Journal of Economic Issues 36 (2), 401-406.

. (2008a), 'Post-Keynesian institutionalism and the anxious society,' in Sandra S. Batie and Nicholas Mercuro (ed.), Alternative Economic Structures: Evolution and Impact, London: Routledge, 273-299.

. (2008b), 'The credit crunch: A Minsky moment,' Studi e Note Di Economia 13 (1), 3-21. . (2008c), ‘Toward ‘wisely managed’ capitalism: Post-Keynesian institutionalism and the creative state,' Forum for Social Economics 37 (1), 43-60.

. (2008d), 'John R. Commons and John Maynard Keynes on economic history and policy: the 1920s and today,' Journal of Economic Issues 42 (1), 225-242. 
. (2008e), 'Reflections on Hyman P. Minsky (1919-1996),' Journal of Economic Issues 42

(1), 249-253.

. (2008f), 'A labor agenda filled with hope and change,' LERA Commons (December 18),

http://lerablog.org/2009/03/18/a-labor-agenda-brimming-with-hope-and-change-by-charles-

whalen/ (accessed April 13, 2009).

. (2009), 'The financial crisis: causes and consequences,' PowerPoint Presentation to the

Finger Lakes Forum (January 19), Geneva, New York.

Wilber, Charles K. and Kenneth P. Jameson. (1983). An Inquiry into the Poverty of Economics,

Notre Dame, Indiana: University of Notre Dame.

Wolfson, Martin H. (1986), Financial Crises: Understanding the Postwar U.S. Experience,

Armonk, New York: M.E. Sharpe.

. (2002), 'Minsky's theory of financial crises in a global context,' Journal of Economic

Issues 36 (2), 393-400.

Wray, L. Randall. (2002), 'What happened to goldilocks? A minskian framework,' Journal of Economic Issues 36 (2), 383-391.

. (2008), 'The commodities market bubble: money manager capitalism and the

financialization of commodities,' Public Policy Brief Number 96, The Levy Economics

Institute of Bard College.

Yahoo Finance. (2009), Dow Jones Industrial Average: Historical Prices, http://finance.yahoo.com (accessed April 13, 2009).

Zalewski, David A. (2002), 'Retirement insecurity in the age of money-manager capitalism,' Journal of Economic Issues 36 (2), 349-356. 